\title{
FAKTOR-FAKTOR YANG MEMPENGARUHI HARGA SAHAM PADA PERUSAHAAN PERBANKAN YANG TERDAFTAR DI BURSA EFEK INDONESIA (BEI)
}

\author{
Ummul Khair ${ }^{1}$, Tri Yuliana ${ }^{2}$, Anwar Junaidi ${ }^{3}$ \\ ${ }^{1,2}$ Fakultas Ekonomi dan Bisnis Universitas Muhammadiyah Bengkulu \\ ${ }^{3}$ Institut Agama Islam Negeri Bengkulu
}

Coresponden Autor : ummulkhair@umb.ac.id,

\begin{abstract}
ABSTRAK
Saat ini, Saham-saham perbankan mengalami pemasalahan karena wabah virus corona (COVID-19) dan ketegangan geopolitik antara Turki dan Rusia menjadi pemicu penurunan indeks. Beberapa perbankan harga sahamnya mengalami penurunan yang sangat besar. Harga saham merupakan harga penutupan pasar saham selama periode pengamatan dan pergerakannya senantiasa diamati oleh para investor. Adapun rumusan masalah pada penelitian ini yaitu apakah Earning Per Share (EPS), Net Profit Margin (NPM), Return On Asset (ROA), dan Return On Equity (ROE) berpengaruh terhadap harga saham. Penelitian ini dilakukan dengan tujuan untuk mengetahui pengaruh faktor-faktor terhadap harga saham Perusahaan Perbankan yang terdaftar di Bursa Efek Indonesia. Penelitian ini menggunakan metode kuantitatif. Populasi Sampel yang digunakan dalam penelitian ini adalah perusahaan perbankan yang terdaftar di BEI selama periode 2016 - 2018 yang berjumlah 44 perusahaan dan jumlah sampel sebanyak 28 perusahaan dipilih dengan menggunakan metode purposive sampling. Hasil penelitian ini menunjukkan bahwa secara parsial, harga saham pada perusahaan perbankan di BEI selama periode 2016 2018 dipengaruhi oleh Earning Per Share (EPS). Sedangakan Net Profit Margin (NPM), Return On Asset (ROA), dan Return On Equity (ROE) tidak berpengaruh terhadap harga saham. Namun secara simultan Earning Per Share (EPS), Net Profit Margin (NPM), Return On Asset (ROA), dan Return On Equity (ROE) berpengaruh terhadap harga saham.
\end{abstract}

\section{Kata kunci : Earning Per Share (EPS), Net Profit Margin (NPM), Return On Asset (ROA), dan Return On Equity (ROE).}

\begin{abstract}
ABSTRAC
Currently, banking stocks are experiencing problems due to the coronavirus (COVID-19) outbreak and geopolitical tracing between Turkey and Russia has triggered the index decline. Several banks' share prices experienced a very large decline. Stock prices, stock market closings during the observation period and their movements are always observed by investors. The formulation of the problem in this study is whether Earning Per Share (EPS), Net Profit Margin (NPM), Return On Asset (ROA), and Return On Equity (ROE) have an effect on stock prices. This research was conducted with the aim of knowing the influence of these factors on the stock price of banking companies listed on the Indonesia Stock Exchange. This research uses quantitative methods. The population sample used in this study were banking companies listed on the IDX during the 2016 - 2018 period which included 44 companies and a total sample of 28 companies selected using the purposive sampling method. The results of this study indicate that partially, share prices in banking companies on the IDX during the $2016-2018$ period rely on Earning Per Share (EPS). Meanwhile, Net Profit Margin (NPM), Return On Asset (ROA), and Return On Equity (ROE) have no effect on stock prices. However, simultaneously Earning Per Share (EPS), Net Profit Margin (NPM), Return On Asset (ROA), and Return On Equity (ROE) have an effect on stock prices.
\end{abstract}

Keywords : Earning Per Share (EPS), Net Profit Margin (NPM), Return On Asset (ROA), and Return On Equity (ROE). 


\section{PENDAHULUAN}

Keberhasilan perekonomian di Indonesia tidak lepas dari sektor perbankan khususnya peran perbankan sebagai sumber pembiayaan industri dalam negeri. Perbankan mempunyai peran strategis dalam menyelaraskan, menyerasikan, serta menyeimbangkan berbagai unsur pembangunan. Menurut UU No. 10 tahun 1998 tentang perbankan, pasal 1 ayat 2, Bank adalah badan usaha yang menghimpun dana dari masyarakat dalam bentuk simpanan dan menyalurkannya kepada masyarakat dalam bentuk kredit dan atau bentuk-bentuk lainnya dalam rangka meningkatkan taraf hidup rakyat banyak. Dalam operasinya bank lebih banyak menggunakan dana masyarakat dibandingkan dengan modal sendiri dari pemilik atau pemegang saham. Oleh sebab itu, pengelola bank dalam melakukan usahanya dituntut untuk menjaga keseimbangan antara pemeliharaan likuiditas yang cukup dengan pencapaian rentabilitas yang wajar serta pemenuhan kebutuhan modal yang memadai sesuai dengan jenis penanamannya. Banyak para pemodal tertarik untuk menginvestasikan dananya dalam bentuk saham karena investasi dalam bentuk saham menjanjikan tingkat keuntungan yang lebih tinggi baik dari dividen maupun capital gain. Akan tetapi investasi dalam bentuk saham juga mempunyai resiko yang tinggi.

Saham merupakan salah satu instrumen pasar keuangan yang paling popular. Menerbitkan saham merupakan salah satu pilihan perusahaan ketika memutuskan untuk pendanaan perusahaan. Pada sisi yang lain, saham merupakan instrument investasi yang banyak dipilih para investor karena saham mampu memberikan tingkat keuntungan yang menarik. Saham dapat didefinisikan sebagai tanda penyertaan modal seseorang atau pihak (badan usaha) dalam suatu perusahaan atau perseroan terbatas. Dengan menyertakan modal tersebut, maka pihak tersebut memiliki klaim atas pendapatan perusahaan, klaim atas asset perusahaan, dan berhak hadir dalam Rapat Umum Pemegang Saham (RUPS) (Menurut BEI). Ada beberapa sudut pandang untuk membedakan saham, yaitu ditinjau dari segi kemampuan dalam hak tagih atau klaim maka saham terbagi atas saham biasa dan saham preferen. Sedangkan, dilihat dari cara peralihannya, saham dapat dibedakan atas saham atas unjuk dan saham atas nama. Pada dasarnya, ada dua keuntungan yang diperoleh investor dengan membeli atau memiliki saham yaitu dengan mendapatkan dividen dan capital gain. Dividen merupakan pembagian keuntungan yang diberikan perusahaan dan berasal dari keuntungan yang dihasilkan perusahaan. Dividen diberikan setelah mendapat persetujuan dari pemegang saham dalam RUPS. Capital gain merupakan selisih antara harga beli dan harga jual. Capital gain terbentuk dengan adanya aktivitas perdagangan saham di pasar sekunder.

Selain keuntungan, saham juga memiliki resiko, antara lain Capital loss Merupakan kebalikan dari Capital gain, yaitu suatu kondisi dimana investor menjual saham lebih rendah dari harga beli. Sedangkan, Risiko Likuidasi Perusahaan yang sahamnya dimiliki, dinyatakan bangkrut oleh Pengadilan, atau perusahaan tersebut dibubarkan. Dalam hal ini hak klaim dari pemegang saham mendapat prioritas terakhir setelah seluruh kewajiban perusahaan dapat dilunasi (dari hasil penjualan kekayaan perusahaan). Jika masih terdapat sisa dari hasil penjualan kekayaan perusahaan tersebut, maka sisa tersebut dibagi secara proporsional kepada seluruh pemegang saham. Namun jika tidak terdapat sisa kekayaan perusahaan, maka pemegang saham tidak akan memperoleh hasil dari likuidasi tersebut. Kondisi ini merupakan risiko yang terberat dari pemegang saham. Untuk itu seorang pemegang saham dituntut secara terus menerus mengikuti perkembangan perusahaan. Namun saat ini, Saham-saham perbankan mengalami pemasalahan karena wabah virus korona (COVID-19) dan ketegangan geopolitik antara Turki dan Rusia menjadi pemicu penurunan indeks. Beberapa perbankan Harganya saham mengalami penurunan yang sangat besar. Pada PT Bank Central Asia Tbk (BBCA), PT Bank Rakyat Indonesia Tbk (BBRI), PT Bank Mandiri Tbk (BMRI), dan PT Bank Negara Indonesia Tbk (BBNI), harganya turun lebih dari 3\%.

IHSG mengalami penurunan sekitar 1,93\%, mengikuti pergerakan indeks Dow Jones yang turun 3,58\%. Wabah virus korona (COVID-19) dan ketegangan geopolitik antara Turki dan Rusia menjadi pemicu penurunan indeks. Sementara itu, di dalam negeri sentimen negatif 
berupa turunnya cadangan devisa serta pemanggilan para bankir agar menurunkan suku bunga dianggap sebagai intervensi otoritas terhadap pasar. Bank Indonesia (BI) melaporkan data cadangan devisa per akhir Februari 2020 sebesar US\$ 130,4 miliar, turun US\$ 1,3 miliar dibanding bulan sebelumnya yang sebesar Rp 131,7 miliar. Harga saham BBCA pagi ini turun 3.03\% menjadi Rp 31.200 dan sempat menyentuh level bawah Rp 31.075. Saham BBRI juga mengalami nasib serupa, harganya turun $3 \%$ ke level Rp 4.020 dan sempat diperdagangkan pada level bawah Rp 4.000. Harga BMRI dan BBNI masing- masing turun 4.28\% dan 4.4\%. BMRI sempat menyentuh level terbawah Rp 7.250, sedangkan BBNI menyentuh level terbawah pada harga Rp 6.475.

Penelitian ini memilih perusahaan perbankan yang terdaftar di Bursa Efek Indonesia sebagai objek penelitian, karena bank merupakan cerminan kepercayaan investor pada stabilitas system keuangan dan system perbankan suatu Negara. Penelitian ini menggunakan rasio keuangan untuk mengukur kinerja perusahaan. Rasio yang digunakan yaitu Earning Per share (EPS), Net Profit Margin (NPM), Return On Assets (ROA), dan Return On Equity (ROE). Penelitian Anisma (2012) mengenai faktor-faktor yang mempengaruhi harga saham perusahaan perbankan yang listing di BEI. Menunjukan hasil bahwa Return On Assets (ROA) dan Net Profit Margin (NPM) berpengaruh positif dan signifikan terhadap harga saham. Pada penelitian Asep dan Resi (2016) menunjukkan hasil bahwa EPS berpengaruh secara parsial sedangkan ROE dan ROA tidak berpengaruh secara parsial. Penelitian Triawan dan Atina (2017) mengenai pengaruh ROA, ROE NPM, dan EPS terhadap harga saham perusahaan di Jakarta Islamic Index (JII) periode 2011-2015. Menunjukkan hasil bahwa ROA, ROE, NPM tidak berpengaruh signifikan terhadap harga saham sedangkan EPS berpengaruh signifikan terhadap harga saham. Penelitian Cahyaningrum (2017) EPS, ROA, dan ROE berpengaruh signifikan terhadap harga saham.

\section{KAJIAN PUSTAKA}

Saham (Stock) sebagai tanda penyertaan atau pemilikan seseorang atau badan dalam suatu perusahaan atau perseroan terbatas. Saham berwujud selembar kertas yang menerangkan bahwa pemilik kertas tersebut adalah pemilik perusahaan yang menerbitkan surat berharga tersebut. Porsi kepemilikan ditentukan oleh seberapa besar penyertaan yang ditanamkan di perusahaan tersebut (Darmadji dan Fakhruddin 2011:5).

Menurut Husnan Suad (2008:29) dalam Kurnia (2015) Saham adalah secarik kertas yang menunjukkan hak pemodal yaitu pihak yang memiliki kertas tersebut untuk memperoleh bagian dari prospek atau kekayaan organisasi yang menerbitkan sekuritas tersebut dan berbagai kondisi yang memungkinkan pemodal tersebut menjalankan haknya.

Menurut BEI, Saham merupakan salah satu instrumen pasar keuangan yang paling popular. Menerbitkan saham merupakan salah satu pilihan perusahaan ketika memutuskan untuk pendanaan perusahaan. Pada sisi yang lain, saham merupakan instrument investasi yang banyak dipilih para investor karena saham mampu memberikan tingkat keuntungan yang menarik. Saham dapat didefinisikan sebagai tanda penyertaan modal seseorang atau pihak (badan usaha) dalam suatu perusahaan atau perseroan terbatas. Dengan menyertakan modal tersebut, maka pihak tersebut memiliki klaim atas pendapatan perusahaan, klaim atas asset perusahaan, dan berhak hadir dalam Rapat Umum Pemegang Saham (RUPS).

Sementra itu harga saham merupakan harga penutupan pasar saham selama periode pengamatan untuk tiap-tiap jenis saham yang dijadikan sampel dan pergerakannya senantiasa diamati oleh para investor. Salah satu konsep dasar dalam manajemen keuangan adalah bahwa tujuan yang ingin dicapai manajemen keuangan adalah memaksimalisasi nilai perusahaan. Bagi perusahaan yang telah go public, tujuan tersebut dapat dicapai dengan cara memaksimalisasi nilai pasar harga sahamyang bersangkutan. Dengan demikian pengambilan keputusan selalu didasarkan pada pertimbangan terhadap maksimalisasi kekayaan para pemegang saham (Nia Kurnia, 2015). 
Menurut Sartono (2008) dalam Alipudin (2016), "Harga saham terbentuk melalui mekanisme permintaan dan penawaran di pasar modal. Apabila suatu saham mengalami kelebihan permintaan, maka harga saham cenderung naik. Sebaliknya, apabila kelebihan penawaran maka harga saham cenderung turun". Sedangkan menurut Jogiyanto (2008) pengertian dari harga saham adalah "Harga suatu saham yang terjadi di pasar bursa pada saat tertentu yang ditentukan oleh pelaku pasar dan ditentukan oleh permintaan dan penawaran saham yang bersangutan di pasar modal". Berbagai factor yang mempengaruhi harga saham, tak terkucuali harga saham juga dapat dipengaruhi oleh kondisi perusahaan. Semakin baik kinerja suatu perusahaan akan berdampak pada laba yang diperoleh perusahaan dan keuntungan yang didapat oleh investor, sehingga akan mempengaruhi peningkatan harga saham.

\section{Earning per share (EPS)}

Earning per share (EPS) atau laba per saham merupakan tingkat keuntungan bersih untuk tiap lembar sahamnya yang mampu diraih perusahaan pada saat menjalankan operasinya (Menurut Perdana, dkk 2013). Menurut Tandelilin (2017:376) Earning per share (EPS) merupakan komponen penting pertama yang harus diperhatikan dalam analisis perusahaan. Bagi para investor, informasi EPS merupakan informasi yang dianggap paling mendasar dan berguna, karena bisa menggambarkan prospek earning perusahaan di masa depan serta sebagai ukuran keefisienan suatu perusahaan. Menurut Kasmir $(2012,207)$ dalam Alipudin dan Resi (2016) EPS merupakan rasio untuk mengukur keberhasilan manajemen dalam mencapai keuntungan bagi pemegang saham.

Dengan demikian, laba per saham (EPS) menunjukan kemampuan perusahaan dalam memperoleh laba dan mendistribusikan laba yang diraih perusahaan kepada pemegang saham. Laba per saham (EPS) dapat dijadikan sebagai indikator tingkat nilai perusahaan. Laba per saham (EPS) juga merupakan salah satu cara untuk mengukur keberhasilan dalam mencapai keuntungan bagi para pemilik saham dalam perusahaan. Kenaikan atau penurunan EPS dari tahun ke tahum adalah ukuran penting untuk mengukur baik tidaknya pekerjaan yang dilakukan perusahaan pemegang saham. Semakin tinggi nilai EPS maka semakin tinggi keuntungan yang didapat para pemegang saham. Sebaliknya jika nilai EPS rendah maka keuntungan yang didapat para pemegang saham juga rendah. Secara teori semakin tinggi EPS, harga saham cenderung naik. EPS yang meningkat akan mendorong investor untuk menambah jumlah modal yang ditanamkan pada perusahaan tersebut, sehingga permintaan terhadap saham tersebut meningkat berakibatkan harga saham juga meningkat.

\section{Net Profit Margin (NPM)}

Dalam kegiatan bisnis, setiap perusahaan tentunya memiliki tujuan utama yaitu beorientasi pada keuntungan. Untuk mendapatkan keuntungan tersebut tentunya perusahaan harus dapat menjual barang lebih tinggi dari pada biaya produksi. Oleh karena itu setiap perusahaan akan selalu melakukan sebuah perencanaan dalam penentuan keuntungan yang akan diperoleh di masa mendatang. Net Profit Margin atau margin laba bersih merupakan rasio profitabilitas untuk menilai persentase laba bersih yang didapat setelah dikurangi pajak terhadap pendapatan yang diperoleh dari penjualan. Para investor pasar modal perlu mengetahui kemampuan perusahaan untuk menghasilkan laba. Dengan mengetahui hal tersebut investor dapat menilai kinerja perusahaan tersebut.

Menurut Bastian \& Suhardjono ( 2006: 299 ) dalam Muhammad ( 2017 ), Net Profit Margin (NPM) adalah perbandingan antara laba bersih dengan penjualan. Semakin besar NPM, maka kinerja perusahaan akan semakin produktif, sehingga akan meningkatkan kepercayaan investor untuk menanamkan modalnya pada perusahaan tersebut. Rasio ini menunjukkan berapa besar persentase laba bersih yang diperoleh dari setiap penjualan. Semakin besar rasio ini, maka dianggap semakin baik kemampuan perusahaan untuk mendapatkan laba yang tinggi.

NPM merupakan rasio keuangan yang mengukur kemampuan bank dalam menghasilkan net income dari kegiatan operasional pokok bank. Rasio ini menggambarkan tingkat keuntungan 
(laba) yang diperoleh bank dibandingkan dengan pendapatan yang diterima dari kegiatan operasionalnya. NPM ini berfungsi untuk mengukur tingkat kembalian keuntungan bersih terhadap penjualan bersihnya. Semakin besar nilai NPM berarti semakin efisien biaya yang dikeluarkan yang berarti semakin besar tingkat kembalian keuntungan bersih (Sudjaja, 2003 : 87 dalam Anisma, 2012).

\section{Return On Assets (ROA)}

Return on assets (ROA) adalah rasio profitabilitas yang mengukur kemampuan perusahaan menghasilkan laba dari penggunaan seluruh sumber daya atau aset yang dimilikinya. Sebagai rasio profitabilitas, ROA digunakan untuk menilai kualitas dan kinerja perusahaan dalam menghasilkan laba bersih dari pemanfaatan aset yang dimilikinya.

Menurut Anisma (2012), ROA adalah rasio yang digunakan untuk mengetahui kemampuan bank menghailkan keuntungan secara relative dibandingkan dengan nilai total assetnya. Rasio ini sangat penting, mengingat keuntungan yang memadai diperlukan untuk mempertahankan sumber-sumber modal bank. ROA menggambarkan sejauh mana kemampuan asset-aset yang dimiliki perusahaan bisa menghasilkan laba (Tandelilin, 2017:374).

ROA dapat pula dipahami sebagai rasio yang digunakan untuk mengukur efisiensi perusahaan dalam menghasilkan pendapatan atau keuntungan dari sumber daya ekonomi atau aset yang dimiliki dalam neracanya. Secara lebih sederhana, ROA dapat didefinisikan sebagai hasil perbandingan antara laba bersih setelah pajak dengan total aset yang dimiliki suatu perusahaan. Rasio ROA dinyatakan dalam persentase. Semakin tinggi atau baik rasio ROA yang dimiliki perusahaan, menandakan semakin baik kinerja perusahaan dalam menghasilkan laba bersih. Demikian pula sebaliknya. Laba bersih yang dimaksudkan dalam rasio keuangan ini adalah laba setelah setelah pajak atau di dalam laporan keuangan sering juga disebut sebagai laba tahun berjalan. Sementara total aset yang dimaksudkan adalah seluruh harta kekayaan yang dimiliki perusahaan baik yang bersumber dari modal sendiri (equity) maupun utang (debt).

\section{Return On Equity (ROE)}

Return On Equity (ROE) merupakan rasio yang digunakan untuk mengukur kemampuan dari modal sendiri untuk menghasilkan keuntungan bagi seluruh pemegang saham. Semakin tinggi nilai ROE, maka akan menarik minat para investor untuk menanamkan modalnya pada perusahaan tersebut, bahwa perusahaan tersebut mempunyai kinerja yang baik dan akibatnya harga saham pun akan ikut naik.

Kabajeh et al. (2012) dalam Cahyaningrum \& Tiara (2017) menyatakan Return on Equity (ROE) adalah rasio profitabilitas yang digunakan untuk mengukur tingkat kembali perusahaan atau efektivitas perusahaan dalam menghasilkan laba yang merupakan hak dari pemilik modal. ROE dihitung sebagai laba bersih setelah pajak dibagi dengan total ekuitas pemegang saham. Rasio ini mengukur tingkat pemegang saham pengembalian investasi mereka dalam perusahaan. Jika perusahaan mendapatkan keuntungan dari penggunaan efektivitas modal maka nilai perusahaan yang ditunjukkan dengan harga saham akan meningkat pula.

Return On Equity (ROE) adalah rasio untuk mengukur kemampuan manajemen dalam pengelolan modal yang ada untuk mendapatkan laba (Kasmir,2012). Menurut Darmadji dan Fakhruddin (2011:158) Return On Equity (ROE) adalah rasio untuk mengukur kemampuan laba atas modal sendiri yang dimiliki perusahaan. Penggunaan rasio ini untuk mengukur bagaimana kemampuan modal sendiri dalam menghasilan keuntung bagi pemilik saham. Jika semaikn tinggi tingkat Return On Equity perusahaan tersebut maka semakin tinggi peluang untuk mendapatkan laba yang besar bagi pemegang saham, sehingga bisa menarik daya minat investor untuk berinvestasi. Semakin banyak investor yang membeli saham perusahaan itu maka menandakan semakin baik kinerja Return On Equity perusahaan tersebut. 


\section{Kerangka Teoritik}

Kerangka teoritik pada penelitian ini dapat digambarkan sebagai berikut :

Gambar 1

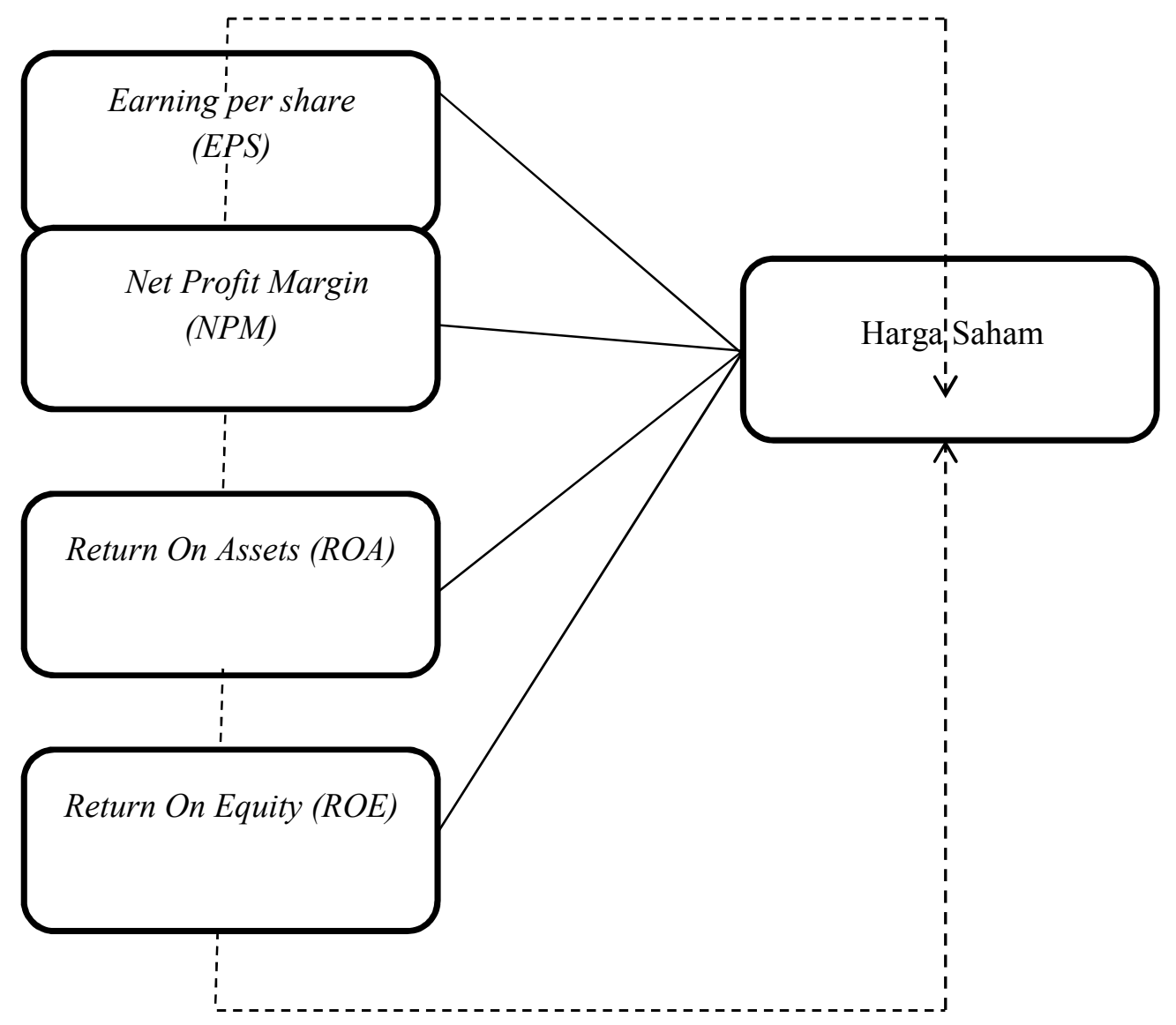




\section{METODOLOGI PENELITIAN}

Penelitian ini menggunakan Metode kuantitatif yaitu metode penelitian yang menghasilkan penemuan-penemuan yang dapat diperoleh dengan prosedur-prosedur statistik atau cara-cara lain dari pengukuran, dan penelitian ini menggunakan alat bantu SPSS. Populasi penelitian ini adalah perusahaan perbankan yang menjadi anggota di Bursa Efek Indonesia periode 2016-2018 sebanyak 44 perusahaan.

Untuk pemilihan sampel peneliti menggunakan metode yaitu Purposive Sampling dengan data sebanyak 28 perusahaan. Data sampel diolah dengan Software SPSS versi 16. Sampel yang telah dipilih selanjutnya digunakan untuk analisis data dan pengujian hipotesis.. Sumber data yang digunakan dalam penelitian ini merupakan data sekunder.

Teknik pengumpulan data menggunakan data sekunder berupa laporan keuangan dan harga saham selama periode penelitian melalui internet dengan website BEI yaitu www.idx.co.id dan website resmi masing-masing perusahaan.

\section{HASIL DAN PEMBAHASAN}

Data yang digunakan dalam penelitian ini adalah data sekunder yang meliputi data dalam bentuk laporan keuangan pada Perusahaan perbankan yang terdaftar pada Bursa Efek Indonesia (BEI). Data sekunder pada penelitian ini di peroleh dengan mengakses situs http://www.idx.co.id dan website masing-masing perusahaan perbankan pada tahun 2016-2018. Dalam penelitian ini terdapat Variabel Independen terdiri dari Earning Per Share, Net Profit Margin, Return On Asset, dan Return On Equity lalu Variabel Dependennya adalah Harga saham. Pada penelitian ini populasi dan sampel di pilih dari perusahaan perbankan yang terdaftar di Bursa Efek Indonesia (BEI) tahun 2016 -2018 Diambilnya perusahaan perbankan sebagai populasi dan sampel dikarenakan perusahaan perbankan mempunyai peranan penting dan dampaknnya sangat besar bagi perekonomian negeri seperti penyimpanan uang, peminjaman uang untuk modal usaha, administrasi keuangan, pertukaran mata uang dan pengiriman uang baik dalam negeri maupun luar negeri.

\section{Hasil dan Pembahasan}

\section{Hasil Uji Analisis Deskriptif}

Analisis deskriptif dilakukan untuk memberikan gambarkan statistik dari variabel yang digunakan didalam penelitian ini yaitu berupa pengukuran mean, standard devisasi, nilai minimal dan nilai maksimal. Hasil uji statistik deskriptif variabel-variabel tersebut dapat dilihat pada tabel 4.3 di bawah ini :

Tabel 1. Hasil Analisis Statistik Deskriptif

Descriptive Statistics

\begin{tabular}{|l|r|r|r|r|r|}
\hline & $\mathrm{N}$ & Minimum & Maximum & \multicolumn{1}{c|}{ Mean } & Std. Deviation \\
\hline EPS & 84 & 2.02 & 1048.54 & 159.6757 & 229.38174 \\
NPM & 84 & 29.22 & 511.04 & 80.0926 & 48.99402 \\
ROA & 84 & .13 & 5.91 & 1.3327 & .88786 \\
ROE & 84 & .78 & 25.54 & 8.4283 & 4.98931 \\
HARGA SAHAM & 84 & 62 & 26000 & 2584.19 & 4324.115 \\
Valid N (listwise) & 84 & & & & \\
\hline
\end{tabular}

Sumber : Data diolah peneliti, 2020 
Tabel 1 diatas menunjukkan bahwa jumlah pengamatan pada perusahaan perbankan yang terdaftar di Bursa Efek Indonesia (BEI) tahun 2016 - 2018 dalam penelitian ini adalah sebanyak 84 data. Dari tabel dapat diketahui bahwa harga saham memiliki nilai minimum sebesar Rp 62 dan nilai maksimum sebesar Rp 26.000. Nilai mean atau rata-rata dari harga saham adalah sebesar Rp 2584.19 sedangkan standar deviasinya sebesar Rp 4324.115. Variabel EPS (X1) memiliki nilai minimum sebesar 2.02 dan nilai maksimum sebesar 1048.54, nilai mean atau rata-rata sebesar 159.6757 dan nilai standar deviasi 229.38174. Variabel NPM (X2) memiliki nilai minimum sebesar 29.22 dan nilai maksimum 511.04. Nilai mean atau rata-rata sebesar 80.0926 dan standar deviasi 48.99402. Variabel ROA (X3) memiliki nilai minimum sebesar 0.13 dan nilai maksimum 5.91 sebesar Nilai mean atau rata-rata sebesar dan standar deviasi 0.88786. Variabel ROE (X4) memiliki nilai minimum sebesar 0.78 dan nilai maksimum sebesar 25.54 Nilai mean atau rata-rata sebesar 8.4283 dan standar deviasi sebesar 4.98931.

\section{Uji Asumsi Klasik \\ Uji Normalitas}

Uji normalitas yang dilakukan didalam penelitain ini memakai Non-Parametrictes, Onesample Kolmogrov Smirnov dengan melihat nilai signifikan dari Asymp. Sig(2-tailed) $>0.05$ maka nilai residual berdistribusi normal. Jika nilai Asymp. Sig (2-tailed) $<0.05$ maka nilai residual berdistribusi tidak normal. Hasil Uji Kolmogorov-Smirnov dapat ditunjukan pada tabel berikut :

Tabel 2. Hasil Uji Normalitas

\section{One-Sample Kolmogorov-Smirnov Test}

\begin{tabular}{|ll|r|}
\hline & & $\begin{array}{c}\text { Unstandardize } \\
\text { d Residual }\end{array}$ \\
\hline $\mathrm{N}$ & & 84 \\
Normal Parameters ${ }^{\mathrm{a}}$ & Mean & .0000000 \\
& Std. Deviation & .68092271 \\
Most Extreme & Absolute & .050 \\
Differences & Positive & .050 \\
& Negative & -.038 \\
Kolmogorov-Smirnov Z & & .455 \\
Asymp. Sig. (2-tailed) & .986 \\
\hline a. Test distribution is Normal. & \\
Sumber : Data diolah peneliti, 2020 & \\
\end{tabular}

Dari tabel 2 diatas diperoleh nilai Asymp. Sig. (2-tailed) sebesar 0.986. Nilai tersebut lebih besar dari 0.05 yang berarti data telah terdistribusi normal. Dengan demikian Uji Normalitas ini menunjukkan bahwa asumsi normalitas terpenuhi.

\section{Uji Multikolinearitas}

Syarat yang harus dipenuhi didalam model regresi pada sebuah penelitan yakni bebas dari masalah multikolinearitas. Pengujian multikolinearitas berguna untuk apakah pada model regresi tersebut ditemukan adanya suatu korelasi yang sempurna atau yang mendekati sempurna antar variabel independen satu sama yang lainnya. Dalam hal ini untuk mengetahui adanya multikolinearitas dapat dilihat dari Value Inflation Factor (VIF). Jika model regresi dinyatakan bebas dari gejala multikolenearitas yaitu nilai Value Inflation Factor (VIF) kurang dari 10 dan mempunyai nilai Tolerance lebih dari 0.1. Uji penelitian bisa dilihat pada tabel 4.5 : 
Tabel 3. Hasil Uji Multikolinearitas

Coefficients $^{\mathrm{a}}$

\begin{tabular}{|c|c|c|c|c|c|c|c|}
\hline \multirow[b]{2}{*}{ Model } & \multicolumn{2}{|c|}{$\begin{array}{l}\text { Unstandardized } \\
\text { Coefficients }\end{array}$} & \multirow{2}{*}{\begin{tabular}{|c}
$\begin{array}{c}\text { Standardized } \\
\text { Coefficients }\end{array}$ \\
Beta \\
\end{tabular}} & \multirow[b]{2}{*}{$\mathrm{t}$} & \multirow[b]{2}{*}{ Sig. } & \multicolumn{2}{|c|}{ Collinearity Statistics } \\
\hline & $\mathrm{B}$ & Std. Error & & & & Tolerance & VIF \\
\hline 1 (Constant) & 4.999 & 1.329 & & 3.762 & .000 & & \\
\hline EPS & .842 & .070 & 1.012 & 11.980 & .000 & .412 & 2.424 \\
\hline NPM & -.194 & .288 & -.037 & -.674 & .502 & .966 & 1.035 \\
\hline ROA & -.053 & .162 & -.031 & -.330 & .743 & .343 & 2.912 \\
\hline ROE & -.301 & .189 & -.167 & -1.593 & .115 & .267 & 3.742 \\
\hline
\end{tabular}

Sumber : Data diolah peneliti, 2020

Dari tabel 3 di atas dapat dilihat bahwa semua variabel memilki nilai Value Inflation Factor (VIF) kurang dari 10 dan mempunyai nilai tolerance lebih dari 0,1. Dengan begitu, dapat disimpulkan bahwa model regresi ini tidak terjadi masalah multikolinearitas.

\section{Uji Heterokedastisitas}

Heteroskedastisitas menguji terjadinya perbedaan variance residual suatu periode pengamatan ke periode pengamatan yang lain. Pengujian heteroskedastisitas pada penelitian ini dideteksi dengan menggunakan Uji Park. Uji Park digunakan dengan cara melakukan pemangkatan terhadap nilai residual lalu dilogaritma natural (di Ln-kan) kemudian dilakukan regresi terhadap variabel bebasnya. Jika variabel independen nilai sig $(\mathrm{sig}>0.05)$ berarti model bebas dari heterokedastisitas.

Tabel 4. Hasil Uji Heterokedastisitas

\begin{tabular}{|c|c|c|c|c|c|c|}
\hline \multirow{2}{*}{\multicolumn{2}{|c|}{ Model }} & \multicolumn{2}{|c|}{ Unstandardized Coefficients } & \multirow{2}{*}{$\begin{array}{c}\begin{array}{c}\text { Standardized } \\
\text { Coefficients }\end{array} \\
\text { Beta }\end{array}$} & \multirow[b]{2}{*}{$\mathrm{t}$} & \multirow[b]{2}{*}{ Sig. } \\
\hline & & $\mathrm{B}$ & Std. Error & & & \\
\hline \multirow[t]{5}{*}{1} & (Constant) & -1.123 & 5.030 & & -.223 & .824 \\
\hline & EPS & .249 & .266 & .157 & .937 & .352 \\
\hline & NPM & -.122 & 1.089 & -.012 & -.112 & .911 \\
\hline & ROA & -.599 & .614 & -.179 & -.976 & .332 \\
\hline & ROE & -.823 & .715 & -.239 & -1.151 & .253 \\
\hline
\end{tabular}

Sumber : Data diolah peneliti, 2020

Berdasarkan tabel 4, bahwa tidak terdapat masalah heterokedastisitas dari masing-masing variabel, hasil menunjukkan nilai signifikansi lebih besar (signifikansi $>0,05$ ). Sehingga tidak menjadi masalah heteroskedastisitas.

\section{Uji Autokorelasi}

Didalam model regresi ada uji autokorelasi. Tujuan dari uji autokorelasi adalah untuk melihat ada atau tidaknya korelasi antar residual pada periode $t$ dengan residual pada periode sebelumnya (t-1). Pada penelitian ini metode pengujian digunakan untuk mendektesi masalah autokorelasi adalah uji Durbin-Watson. Adapun pengambilan keputusan dalam uji DurbinWarson adalah sebagai berikut : 
a. Jika $\mathrm{Du}<\mathrm{Dw}<4$ - Du maka Ho diterima itu berarti tidak terjadi autokorelasi positif dan negatif.

b. $\quad$ Jika $\mathrm{D} 1 \leq \mathrm{Dw} \leq \mathrm{Du}$ atau 4-Du $\leq \mathrm{Dw} \leq 4$-D1 maka Ho ditolak artinya tidak ada kepastian atau kesimpulan yang pasti.

c. Jika $0<\mathrm{Dw}<\mathrm{D} 1$ Ho ditolak yang berarti tidak terdapat auto korelasi positif d. Jika 4 -Du $\leq \mathrm{Dw} \leq 4$-D1 maka Ho ditolak yang berarti tidak terdapat autokorelasi negatif

Tabel 5. Hasil Uji Autokorelasi

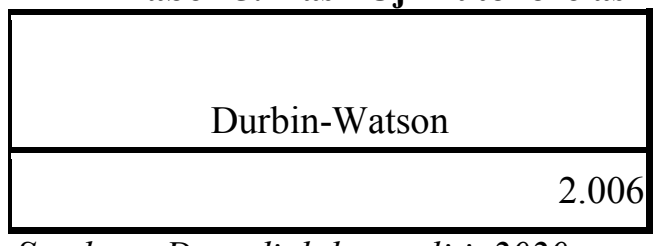

Sumber : Data diolah peneliti, 2020

Dalam penelitian ini, jumlah observasi $(\mathrm{n})=84$ dan jumlah variabel bebas atau independen $(\mathrm{k})=4$, maka dari tabel Durbin-Watson (DW) dengan $\alpha=5 \%$, nilai dU sebesar 1.7462 sedangkan nilai 4 - dU adalah 2.2538. Agar model regresi ini tidak terjadinya autokorelasi, maka nilai Durbin-Watson (DW) haruslah diantara 1.7462 dan 2.2538. Hasil output di atas menunjukkan nilai DW $=2.006$ dan terletak diantara 1.7462 dan 2.2538. Jadi dapat disimpulkan bahwa pada model regresi ini tidak terjadi autokorelasi.

\section{Uji Regresi Linear Berganda}

Pada dasarnya analisis ini mendeskirpsikan hubungan linear dari beberapa variabel independen (X) terhadap variabel dependen (Y) (Ghozali,2011). untuk persamaan Regresi bisa diperoleh dengan melihat nilai pada tabel Unstandardized Coefficients. Nilai ouput bisa dilihat pada tabel Persamaan regresi diperoleh dengan melihat nilai pada tabel tabel 4.8 berikut ini.

Tabel 6. Hasil Uji Regresi Linier Berganda

\begin{tabular}{|c|c|c|c|c|c|c|c|}
\hline \multirow[b]{2}{*}{ Model } & \multicolumn{2}{|c|}{$\begin{array}{l}\text { Unstandardized } \\
\text { Coefficients }\end{array}$} & \multirow{2}{*}{$\begin{array}{c}\begin{array}{c}\text { Standardized } \\
\text { Coefficients }\end{array} \\
\text { Beta }\end{array}$} & \multirow[b]{2}{*}{$\mathrm{t}$} & \multirow[b]{2}{*}{ Sig. } & \multicolumn{2}{|c|}{ Collinearity Statistics } \\
\hline & $\mathrm{B}$ & Std. Error & & & & Tolerance & VIF \\
\hline 1 (Constant) & 4.999 & 1.329 & & 3.762 & .000 & & \\
\hline EPS & .842 & .070 & 1.012 & 11.980 & .000 & .412 & 2.424 \\
\hline NPM & -.194 & .288 & -.037 & -.674 & .502 & .966 & 1.035 \\
\hline ROA & -.053 & .162 & -.031 & -.330 & .743 & .343 & 2.912 \\
\hline ROE & -.301 & .189 & -.167 & -1.593 & .115 & .267 & 3.742 \\
\hline
\end{tabular}

Sumber : Data diolah peneliti, 2020

Dari proses pengolahan data yang telah dilakukan diperoleh ringkasan hasil pengujian seperti yang terlihat pada persamaan regresi linier berganda berikut:

$\mathrm{Y}=4.999+0.842 \times 1-0.194 \times 2-0.053 \times 3-0.301 \times 4$

Berdasarkan model regresi dan tabel 8 diatas maka hasil regresi berganda dapat dijelaskan sebagai berikut:

- Nilai konstanta sebesar 4.999. menyatakan apabila variabel bebas lainnya dianggap tetap atau nol (0), maka harga saham (Y) nilai adalah 4.999.

- Koefesian regresi variabel EPS (X1) sebesar 0.842 artinya jika EPS (X1) mengalami peningkatan $1 \%$ dengan asumsi variabel independen lain bernilai tetap atau nol (0), maka Harga saham (Y) akan mengalami peningkatan sebesar 0.842 . 
- Koefesien regresi variabel NPM (X2) sebesar -0.194 artinya jika NPM (X2) mengalami peningkatan sebesar $1 \%$ dengan asumsi variabel independen lain bernilai tetap atau nol (0), maka harga saham (Y) akan mengalami penurunan sebesar -0.194 .

- Koefesien regresi variabel ROA (X3) sebesar -0.053 berarti jika ROA (X3) mengalami peningkatan $1 \%$ dengan asumsi variabel independen lain bernilai tetap atau nol (0), maka harga saham (Y) akan mengalami penurunan sebesar -0.053.

- Koefesien regresi variabel ROE (X4) sebesar 0.301 artinya jika ROE (X4) megalami peningkatan $1 \%$ dengan asumsi variabel independen lain bernilai tetap atau nol (0), maka harga saham (Y) akan mengalami penurunam sebesar 0.301 .

\section{Uji Hipotesis}

\section{Uji t (Uji parsial)}

Uji t ini bertujuan untuk menguji masing-masing dari variabel independen apakah berpengaruh secara parsial terhadap variabel dependen. Dasar pengambilan keputusan Jika nilai $\mathrm{t}_{\text {hitung }}>\mathrm{t}_{\text {tabel }}$ maka variabel bebas (X) berpengaruh terhadap variabel terikat (Y).Jika nilai $\mathrm{t}_{\text {hitung }}$ $\leq \mathrm{t}_{\text {tabel }}$ maka variabel bebas $(\mathrm{X})$ tidak berpengaruh terhadap variabel terikat $(\mathrm{Y})$. Dan jika nilai signifikansi $>0.05$ artinya variabel bebas secara parsial tidak berpengaruh signifikan terhadap variabel terikat. Jika nilai probabilitas signifikansi $<0.05$, arti bahwa variabel bebas secara parsial berpengaruh signifikan terhadap variabel terikat. Nilai t tabel adalah 1.664. Hasil dari perhitungan untuk masing-masing variabel dapat dilihat pada tabel 4.9 dibawah ini :

\section{Tabel 7. Hasil Uji T}

\begin{tabular}{|c|c|c|c|c|c|c|}
\hline & & \multicolumn{2}{|c|}{$\begin{array}{l}\text { Unstandardized } \\
\text { Coefficients }\end{array}$} & $\begin{array}{l}\text { Standardized } \\
\text { Coefficients }\end{array}$ & \multirow[b]{2}{*}{$\mathrm{t}$} & \multirow[b]{2}{*}{ Sig. } \\
\hline \multicolumn{2}{|c|}{ Model } & B & Std. Error & Beta & & \\
\hline 1 & (Constant) & 4.999 & 1.329 & & 3.762 & .000 \\
\hline & EPS & .842 & .070 & 1.012 & 11.980 & .000 \\
\hline & NPM & -.194 & .288 & -.037 & -.674 & .502 \\
\hline & $\mathrm{ROA}$ & -.053 & .162 & -.031 & -.330 & .743 \\
\hline & ROE & -.301 & .189 & -.167 & -1.593 & .115 \\
\hline
\end{tabular}

Sumber : Data diolah peneliti, 2020

Berdasarkan tabel 7 hasil uji t diatas, didapatkan hasil perhitungan sebagai berikut :

1. H1 : Earning per share (EPS) berpengaruh signifikan terhadap harga saham

Nilai t hitung EPS (X1) adalah 11.980 Nilai t hitung lebih besar dari t tabel (11.980 > 1.664) dengan nilai signifikansi berada dibawah atau $(0.000<0.05)$ maka Ho ditolak dan Ha diterima, artinya terdapat pengaruh yang signifikan dari EPS (X1) terhadap harga saham (Y).

2. H2: Net Profit Margin (NPM) berpengaruh signifikan terhadap harga saham

Nilai t hitung NPM (X2) adalah -0.674. Nilai t hitung sendiri lebih kecil dari t tabel ($0.674<1.664)$ dengan nilai signifikansi berada diatas atau $(0.502>0.05)$ maka Ho diterima dan Ha ditolak, artinya tidak ada pengaruh yang signifikan dari NPM (X2) terhadap harga saham $(\mathrm{Y})$.

3. H3 : Return On Assets (ROA) berpengaruh signifikan terhadap harga saham

Nilai t hitung ROA (X3) adalah -0.330 . Nilai t hitung sendiri lebih kecil dari t tabel ($0.330<1.664)$ dengan nilai signifikansi berada diatas atau $(0.743>0.05)$ maka Ho 
diterima dan Ha ditolak, artinya tidak ada pengaruh yang signifikan dari ROA (X3) terhadap harga saham(Y).

4. $\quad \mathrm{H} 4$ : Return On Equity (ROE) berpengaruh signifikan terhadap harga saham

Nilai t hitung ROE (X4) adalah -1.593 Nilai t hitung sendiri lebih kecil dari t tabel ($1.593<1.664)$ dengan nilai signifikansi berada diatas atau $(0.115>0.05)$ maka Ho diterima dan Ha ditolak, artinya tidak ada pengaruh yang signifikan dari ROE (X4) terhadap harga saham (Y).

\section{Uji F (Secara Simultan)}

Uji $F$ bertujuan untuk mengetahui bahwanya variabel independen secara bersama-sama berpengaruh signifikan terhadap variabel dependen. Hasil uji ini bisa dilihat dari tabel output Anova. Hasil perhitungan uji $\mathrm{F}$ dapat dilihat pada tabel 4.10 dibawah ini :

Tabel 8. Hasil Uji F

\begin{tabular}{|c|c|c|c|c|c|c|}
\hline \multicolumn{2}{|c|}{ Model } & $\begin{array}{l}\text { Sum of } \\
\text { Squares }\end{array}$ & Df & Mean Square & $F$ & Sig. \\
\hline 1 & Regression & 126.867 & 4 & 31.717 & 65.109 & $.000^{\circ}$ \\
\hline & Residual & 38.483 & 79 & .487 & & \\
\hline & Total & 165.351 & 83 & & & \\
\hline
\end{tabular}

Sumber : Data diolah peneliti, 2020

Dari tabel 8 diatas yang ditampilkan pada hasil uji $\mathrm{F}$ bertujuan untuk menguji apakah semua variabel independen atau bebas yang dimasukan ke dalam modal apakah mempengaruhi secara bersama-sama terhadap variabel dependen, dengan tingkat signifikan $5 \%$ dan dari hitungan tersebut diperoleh nilai signifikansi $(0.000<0.05)$. Nilai F hitung yakni sebesar 65.109 nilai $\mathrm{F}$ tabel adalah 2.49. Karena $\mathrm{F}$ hitung $>\mathrm{F}$ tabel $(65.109>2.49)$ maka Ho ditolak dan Ha diterima. Sehingga bisa dikatakan bahwa EPS. NPM. ROA dan ROE secara bersama-sama berpengaruh signifikan terhadap harga saham perusahaan perbankan yang terdaftar di Bursa Efek Indonesia periode 2016-2018

\section{Koefisien Determinasi (R2)}

Pada intinya Koefesien Determinasi (R2) mengukur seberapa besar pengaruh variabel independen menerangkan variabel dependen. Untuk lebih jelasnya dapat dilihat dari tabel 4.11 dibawah ini:

Tabel 9. Hasil Uji Koefiesien Determinasi

\begin{tabular}{|l|r|r|r|r|}
\hline Model & \multicolumn{1}{|c|}{ R } & R Square & $\begin{array}{c}\text { Adjusted R } \\
\text { Square }\end{array}$ & $\begin{array}{c}\text { Std. Error of } \\
\text { the Estimate }\end{array}$ \\
\hline 1 & $.910^{\mathrm{a}}$ & .827 & .819 & 1841.757 \\
\hline
\end{tabular}

Sumber : Data diolah peneliti, 2020

Pada tabel 9 diatas bisa diketahui bahwa nilai adjusted $\mathrm{R}^{2}$ sebesar 0.819 atau $81.9 \%$. Hal ini menunjukan arti bahwa variabel EPS, NPM, ROA dan ROE memberikan pengaruh sebesar $81.9 \%$ terhadap Kinerja Keuangan (Y) dan sisanya 18.1\% dipengaruhi oleh faktor-faktor lain.

\section{Pembahasan}

\section{Pengaruh Earning Per Share (EPS) Terhadap Harga saham}

Pada penelitian ini EPS berpengaruh signifikan terhadap harga saham. Hasil ini dapat dlihat pada $t$ tabel proporsi EPS $(11.980>1.664)$ dan nilai signifikansi yang kecil dari $(0.000<0.05)$. 
Para investor sebagai pemegang saham tentunya sangat memperhatikan pendapatan dan pertumbuhan perusahaannya. Dengan meningkatnya pendapatan dan pertumbuhan perusahaan akan meningkatkan keuntungan kepada para investor sebagai pemegang saham. Jika laba per lembar saham tinggi maka jumlah permintaan terhadap saham perusahaan akan meningkat, sehingga harga saham perusahaan akan naik. Hasil penelitian ini menujukkan bahwa investor sangat memperhatikan faktor EPS dalam pengambilan keputusan. Hasil penelitian ini sejalan dengan penelitian yang dilakukan oleh Alipudin (2016), yang menyatakan bahwa EPS berpengaruh terhadap harga saham. Hasil penelitian ini bertentangan dengan hasil penelitian Regina dan Rosmita (2019) yang menujukkan bahwa EPS tidak berpengaruh terhadap harga saham. (Yusmaniarti \& Oktaria, 2019)

\section{Pengaruh Net Profit Margin (NPM) Terhadap Harga saham}

Pada penelitian ini NPM tidak berpengaruh signifikan terhadap harga saham. hasil ini bisa kita lihat didalam Uji t pada $t$ hitung yang mana nilai ROE kecil $(-0.674<1.664)$ dengan nilai signifikansi $(0.502>0.05)$. NPM bertujuan untuk mengetahui secara langsung keuntungan bersih dari suatu bank. Ditinjau dari sudut manajemen, baik atau buruknya kinerja bank dapat dilihat dari besar atau kecilnya nilai NPM. Semakin besar nilai NPM suatu bank berarti semakin baik kinerja bank tersebut. Hal ini disebabkan karena semakin besarnya nilai NPM suatu bank, maka akan semakin besar pula keuntungan marjinal yang diperoleh oleh bank tersebut, menurut Sartono (2002) dalam Anisma (2012). Sehingga pelaku pasar modal akan memberikan tanggapan yang positif, dimana investor akan lebih tertarik untuk menanamkan modalnya pada bank tersebut karena mampu dianggap mampu menghasilkan laba dari kegiatan operasi pokoknya. Dengan kata lain, semakin besar NPM suatu bank maka akan semakin besar pula harga sahamnya. Hasil penelitian ini meninjukkan bahwa investor kurang memperhatikan NPM dalam pengambilan keputusan investasinya.

Hasil penelitian ini sejalan dengan penelitian yang dilakukan oleh Rinaldi (2017) yang menyatakan bahwa NPM tidak berpengaruh terhadap harga saham. Hasil penelitian ini bertentangan dengan hasil penelitian Anisma (2012) yang menujukkan bahwa EPS berpengaruh terhadap harga saham.

\section{Pengaruh Return On Asset Terhadap Harga saham}

Pada penelitian ini Return On Asset (ROA) tidak berpengaruh signifikan terhadap harga saham. hal ini dapat kita lihat secara parsial dalam Uji t bahwa nilai ROA besar $(-0.330<1.664)$ dengan nilai signifikansi $(0.743>0.05)$. Return on assets $(\mathrm{ROA})$ adalah rasio profitabilitas yang mengukur kemampuan perusahaan menghasilkan laba dari penggunaan seluruh sumber daya atau aset yang dimilikinya. Sebagai rasio profitabilitas, ROA digunakan untuk menilai kualitas dan kinerja perusahaan dalam menghasilkan laba bersih dari pemanfaatan aset yang dimilikinya.(Yusmaniarti, 2020)

Semakin tinggi atau baik rasio ROA yang dimiliki perusahaan, menandakan semakin baik kinerja perusahaan dalam menghasilkan laba bersih. Demikian pula sebaliknya. Dalam penelitian ini menunjukkan bahwa kurang baiknya kinerja perusahaan dalam menghasilkan laba. Penelitian ini sejalan dengan penelitian Alipudin dan Resi (2016) yang menyatakan bahwa ROA tidak berpengaruh signifikan terhadap harga saham. Namun berbeda dengan penelitian Cahyaningrum dan Tiara (2017) yang menyatakan bahwa ROA berpengaruh signifikan terhadap harga saham.

\section{Pengaruh Return On Equity Terhadap Harga saham}

Pada penelitian ini Return On Equity tidak berpengaruh signifikan terhadap harga saham. hasil ini bisa kita lihat secara parsial didalam Uji t pada t hitung yang mana nilai ROE kecil (-1.593 < 1.664) dengan nilai signifikansi $(0.115>0.05)$. Return On Equity (ROE) dalam hal ini hanya menggambarkan kemampuan perusahaan dalam menghasilkan keuntungan dengan investasi para pemilik, namun kurang menggambarkan perkembangan dan prospek perusahaan sehingga 
para investor tidak begitu mempertimbangkan ROE sebagai pertimbangan investasinya. Penelitian ini sejalan dengan penelitian Regina dan Rosmita (2019) dan Triawan, Atina (2017) yang menyatakan bahwa ROE tidak berpengaruh signifikan terhadap harga saham.

\section{KESIMPULAN}

Penelitan ini bertujuan untuk mengetahui pengaruh Earning Per Share (EPS), Net Profit Margin (NPM), Return On Assets (ROA), dan Return On Equity (ROE) terhadap harga saham perusahaan perbankan yang terdaftar di Bursa Efek Indonesia (BEI) periode 2016 - 2018 dengan menggunakan sampel sebanyak 84 data observasi. Berdasarkan hasil pembahasan, maka didapatkan kesimpulan sebagai bahwa Secara parsial variabel Earning Per Share (EPS) berpengaruh signifikan terhadap harga saham. Sedangkan variabel lainnya seperti Net Profit Margin (NPM), Return On Assets (ROA), dan Return On Equity (ROE) tidak berpengaruh signifikan terhadap harga saham dan Secara simultan atau bersama - sama, Earning Per Share (EPS), Net Profit Margin (NPM), Return On Assets (ROA), dan Return On Equity (ROE) berpengaruh signifikan terhadap harga saham.

\section{DAFTAR PUSTAKA}

Alipudin, Asep dan Resi Oktaviani. 2016. Pengaruh EPS,ROE,ROA, dan DER Terhadap Harga Saham Pada Perusahaan Sub Sektor Semen Yang Terdaftar Di BEI. JIAFE (Jurnal Ilmiah Akuntansi Fakultas Ekonomi) Volume 2 No. 1 Tahun 2016 Edisi 1, Hal. 1-22

Anisma, Yuneita. 2012. Faktor-Faktor Yang Mempengaruhi Harga Saham Perusahaan Perbankan Yang Listing Di Bursa Efek Indonesia (BEI). Jurnal Sosial Ekonomi Pembangunan Tahun II.

Cahyaningrum, Yustina Wahyu dan Tiara Widya Antikasari. 2017. Pengaruh Earning Per Share, Price To Book Value, Return On Asset, dan Return On Equity Terhadap Harga Saham Sektor Keuangan. Jurnal Economia, Volume 13, Nomor 2, Oktober 2017.

Darmadji Dan Fakhruddin. 2011. Pasar Modal Di Indonesia Edisi 3. Penerbit Salemba Empat.Jakarta

Iman Ghozali. Aplikasi analisi multivariete dengan program IBM SPSS 23, Semarang: Universitas Diponegoro. 2013.

Kurnia, Nia. 2015. Analisis Pengaruh Debt To Equity Ratio (DER) Dan Net Profit Margin (NPM) Terhadap Harga Saham Pada Perusahaan Sektor Aneka Industri Yang Terdaftar

Di Bursa Efek Indonesia Tahun 2011-2013. Politeknik Negeri Sriwijaya. Palembang.

Mega Diah Alnikmatus Sholihah Dan Isana Yuningsih (2018) "Faktor Internal Dan Faktor Eksteral Yang Mempengaruhi Non Performing Financing", Samarinda : Simposium Nasional Akuntansi XXI

Muhammad, Arie Setyawan. 2017. Pengaruh Ukuran Perusahaan, Net Profit Margin (NPM) Dan Return On Equity (ROE) Terhadap Harga Saham. Jurnal Profita Edisi 6.

Perdana, Risky Agustine Putri Dan Nengah Sudjana. 2013. Pengaruh Return On Equity (ROE), Earning Per Share (EPS), Dan Debt Equity Ratio (DER) Terhadap Harga Saham (Studi Pada Perusahaan Makanan Dan Minuman Yang Go Public Di Bursa Efek Indonesia Periode 2008-2011). Jurnal Administrasi Bisnis (JAB) Vol. 2 No. 1 Mei 2013.

Regina Dan Rosmita Rasyid. 2019. Faktor-Faktor Yang Mempengaruhi Harga Saham Pada Perusahaan Manufaktur Di BEI. Jurnal Multiparadigm Akuntansi Volume I No. 2/2019 Hal: 220-228. Jakarta

Siti Nurhasanah.2016. Pratikum statistik 1 dan 2 untuk ekonomi bisnis ,Jakarta : Salemba Empat.

Sugiyono. 2007. Metode Penelitian Kuantitatif Dan Kualitatif Dan R\&D. Bandung: Alfabeta.

Sugiyono. 2016. Metode Penelitian Kuantitatif Dan Kualitatif Dan R\&D. Bandung: Alfabeta. 
Syahputri, Pratami. 2018. Analisis Faktor- Faktor Yang Mempengaruhi Harga Saham Pada Perusahaan LQ45 Di Bursa Efek Indonesia Tahun 2014-2016. Universitas Pasir Pengaraian. Rokan Hulu.

Tandelilin, Eduardus. 2017. Pasar Modal : Manajemen Portofolio Dan Investasi. Penerbit PT Kanisus. Yogyakarta.

Yulhasnita. 2011. Pengaruh Capital Adequacy Ratio, Retrun On Asset, Retrun On Equity, Beban Operasional Terhadap Pendapatan Operasional, Dan Loan Deposit Ratio Terhadap Penyaluran Kredit. Universitas Riau

Yusmaniarti, Y. (2020). Analisis Kinerja Keuangan Perusahaan Sebelum dan Sesudah Initial Public Offering ( IPO ) di Bursa Efek Indonesia. JSMBI (Jurnal Sains Manajemen Dan Bisnis Indonesia, 10(2), 129-245. https://doi.org/DOI : 10.32528/jsmbi.v10i2.4122

Yusmaniarti, Y., \& Oktaria, S. (2019). Pengaruh Earning Per Share, Operating Cash Flow, Economic Value Added (Eva), Dan Market Value Added (Mva)Terhadap Return Saham (Studi Pada Perusahaanmanufaktur Sektor Industri Dasar Dan Kimia Yang Terdaftar Pada Bursa Efek Indonesia Tahun 2013-2015). Bilancia: Jurnal Ilmiah Akuntansi, 3(2), 124136. 